IDEIAS FUNDADORAS

\title{
Apresentação
}

\section{Victor Pelaez}

Professor do Departamento de Economia da Universidade Federal do Paraná

\author{
A história não tem sentido (...) [mas] é inteligivel \\ Michel Foucault
}

Professor emérito de políticas públicas do Departamento de Economia da Universidade de Stanford, Nathan Rosenberg possui uma profícua carreira acadêmica, da qual se pode ter uma ideia a partir de seus 18 livros publicados nas últimas cinco décadas. Em 1994 a revista Research Policy publicou um número especial em homenagem a este autor que completava então 65 anos. Os artigos daquela edição discutiam parte da diversidade de assuntos, tratados por Rosenberg, associados ao que poder-se-ia denominar sinteticamente de "história econômica e política da inovação tecnológica".

Suas contribuições aos estudos econômicos sobre inovação tecnológica ocorreram, sobretudo, no entendimento das relaçôes entre ciência e tecnologia e na importância econômica das inovaçōes incrementais. Esses foram dois aspectos negligenciados por Schumpeter, ao considerar a pesquisa uma atividade exógena à economia e ao dar ênfase às inovações radicais como fonte de explicação da dinâmica econômica.

Ao se converter, como disse Rosenberg, em um historiador econômico e um historiador noviço da tecnologia, ele pôde criticar, de forma mais consistente, as

1 Research Policy, v. 23, n. 5, 1994. 
limitações das teorias econômicas (neoclássica e de Schumpeter) no que tange à geração e difusão da tecnologia. Ao identificar a singularidade das tecnologias em sua transformação ao longo do tempo e dos contextos socioeconômicos e políticos nos quais se inserem, Rosenberg contribuiu para revelar a importância de se passar do geral ao específico na análise de um objeto de estudo essencialmente heterogêneo e dinâmico. Como ele comenta na introdução de um de seus livros: "Deve-se passar do geral ao específico, de 'Tecnologia' a 'tecnologias'. Deve-se inclusive estar preparado para 'sujar as mãos' a fim de adquirir familiaridade com os detalhes importantes inerentes à tecnologia”. ${ }^{2}$ Sua análise histórica abrangeu, assim, estudos e discussôes sobre o processo decisório e a coordenação de recursos associados à inovação tecnológica ao nível da empresa, da indústria e das políticas públicas nas economias industrializadas e em fase de industrialização.

No artigo que aqui se apresenta, Rosenberg propõe-se a discutir a forma como os problemas da mudança técnica são formulados no âmbito da empresa. Ele coloca especificamente a questão: quais são as forças ou mecanismos que determinam a direção da inovação adotada pela empresa? Seu ponto de partida é a crítica a uma análise neoclássica simplificadora, que considera a mudança técnica o resultado de ajustes realizados na função de produção, a partir de sinais obtidos no mercado, notadamente o comportamento dos preços dos fatores. Sua argumentação é a de que esse tipo de generalização, ainda que coerente, carece de consistência, pois tende a mascarar aspectos determinantes nas decisões tomadas pela empresa no processo de inovação. Como contra-argumento, Rosenberg identifica ao menos quatro mecanismos que historicamente têm influenciado o processo decisório de mudança técnica ao nível da empresa. O primeiro diz respeito à interdependência técnica dos processos industriais que se tornaram cada vez mais complexos. Isto faz com que o aperfeiçoamento de determinado equipamento implique a criação de gargalos tecnológicos - na transmissão e/ou no controle de elementos ou etapas do processo produtivo - capazes de impedir a adoção de uma nova tecnologia. $\mathrm{O}$ segundo baseia-se na análise de Marx sobre o interesse do capitalista em substituir o capital por trabalho, a fim de reduzir os riscos associados aos movimentos de resistência da classe trabalhadora. O terceiro está associado ao acesso a matériasprimas, cuja continuidade pode ser ameaçada pela perda de controle das fontes de acesso ou pela possibilidade da existência ou desenvolvimento de fontes alternativas. Este fato marcou o desenvolvimento extraordinário da indústria química alemã na

2 ROSENBERG, N. Tecnologia y economia. Barcelona: Gustavo Gili, 1979, p. 10. 
Segunda Revolução Industrial. E o quarto chama a atenção para um fator, cada vez mais importante, relativo à regulamentação da tecnologia no que tange aos seus efeitos adversos à saúde humana e ao ambiente. As restrições impostas por órgãos reguladores em países industrial e democraticamente mais avançados tornam-se variáveis determinantes na formulação e solução de problemas técnicos complexos. As soluções obtidas podem implicar, a princípio, aumentos de custos e, ao mesmo tempo, determinantes de acesso a mercados.

$\mathrm{O}$ argumento de Rosenberg é que a superação dessas restrições, que tendem a combinar-se ao longo do tempo, representa muitas vezes as causas, cujos efeitos podem se expressar no mercado por meio dos preços. Estes podem ser portanto um efeito e não a causa do ritmo e da direção da mudança técnica. Ao enfatizar a singularidade histórica dos acontecimentos, ele destaca a importância de uma análise microeconômica capaz de seguir os atores em suas rotinas de tomada de decisão. Isto significa perseguir as singularidades históricas que põem continuamente em questão a coerência, o sentido das teorias. Isto significa dizer que um dos maiores legados de Rosenberg às teorias da inovação tecnológica é sua provocação histórica. 



\title{
The Direction of Technological Change: Inducement Mechanisms and Focusing Devices*
}

\author{
Nathan Rosenberg \\ University of Wisconsin
}

\section{Introduction}

One of the things which is perfectly obvious about societies which have achieved high degrees of industrialization is that they have acquired unusual skills in problem-solving activities. Industrial societies have learned how to solve certain kinds of problems, and understanding this creative capacity is basic to an understanding of the growth process. What is less obvious, however, is that the developed countries never solve more than a small fraction of the problems they are capable of solving. Rather, they solve some fraction of the problems which happen to be formulated and actively pursued. This suggests that our understanding of the process of technological change may be advanced by exploring the manner in which problems are formulated at the firm level.

This paper is intended as a sort of historical reconnaissance mission. It represents an attempt to establish certain generalizations concerning the problem-solving process in industrializing countries in the past two centuries. Our interest is in the forces which provide inducements to technical change, and in examining these forces-what Hirschman has called "inducement mechanism"1 - we will not confine ourselves to the more conventional framework of economic reasoning. Indeed, the present paper has been prompted in some measure by the extreme agnosticism to which one is led on the subject of technological change by recent theorizing. It used to be thought possible to explain the factor-saving bias, which inventions took, in purely economic terms. It will be recalled that Hicks stated, in his Theory of Wages:

The real reason for the predominance of labour-saving inventions is surely that which was hinted at in our discussion of substitution. A change in the relative prices of the factors of production is itself a spur to invention, and to

* The author has benefited from discussions with Edward Ames, Albert Hirschman, William Parker, Charles Plott, Eugene Smolensky, and Paul Strassmann.

${ }^{1}$ Albert O. Hirschman, The Strategy of Economic Development (New Haven, Conn.: Yale University Press, 1958), pp. 24-28; see also chap. 8. 
Nathan Rosenberg

\section{Economic Development and Cultural Change}

invention of a particular kind-directed to economizing the use of a factor which has become relatively expensive. The general tendency to a more rapid increase of capital than labour which has marked European history during the last few centuries has naturally provided a stimulus to labour-saving invention. ${ }^{2}$

It now turns out that, at least within the framework of a purely competitive mọdel, we cannot even say this much. For, as has been pointed out in several places, Hicks's position that changes in factor prices lead to innovations involves a confusion between technological change and factor substitution. The current position, as expressed by Fellner, Salter, Samuelson, and others, is that under competitive conditions an individual firm is simply not interested in the particular factor-saving bias of technical improvements. The argument is that a firm always has an incentive to reduce any portion of its costs. The market mechanism provides no incentive to look for inventions which have any particular factor-saving bias. Indeed, the position is that in competitive equilibrium it does not even make sense to speak of "dear" labor or "cheap" labor. After all, when each factor is being paid the value of its marginal product, then all factors are equally "cheap" and equally "dear" in the eyes of a competitive firm.

Salter's position may be quoted as representative of a larger genus. Speaking of Hicks's theory of induced inventions, he stated: "If . . . the theory implies that dearer labor stimulates the search for new knowledge aimed specifically at saving labor, then it is open to serious objections. The entrepreneur is interested in reducing costs in total, not particular costs such as labor costs or capital costs. When labor costs rise any advance that reduces total cost is welcome, and whether this is achieved by saving labor or capital is irrelevant. There is no reason to assume that attention should be concentrated on labor-saving techniques." 3

This is, in a sense, very disquieting-not only because economic historians have long used differences in factor prices (and differences in rates of change of factor prices) as an explanation for the particular factor-saving bias of technological change. More importantly, the individuals directly involved in the process have, on numerous occasions, explained their own

2 J. R. Hicks, The Theory of Wages (New York: Macmillan Co., 1932), pp. 124-25.

${ }^{3}$ W. E. G. Salter, Productivity and Technical Change (New York: Cambridge University Press, 1960), pp. 43-44. Cf. Fellner's succinct statement that "in the event of purely competitive factor hiring, with no factor rationing to individual firms, the market provides no incentive to seek for any given factor inputs one rather than another distribution of the factor-saving effects" (W. Fellner, "Does the Market Direct the Relative Factor-saving Effects of Technological Progress?" in Universities-National Bureau Committee for Economic Research, The Rate and Direction of Inventive Activity [Princeton N.J.: Princeton University Press, 1962], p. 177). See also Paul Samuelson, "A Theory of Induced Innovation along Kennedy-Weisacker Lines," Review of Economics and Statistics (November 1965).

2 


\section{Nathan Rosenberg}

intent and motivation in these terms. Their contemporaries, especially in the nineteenth century, employed similar explanations with almost monotonous regularity.

Perhaps what is needed is to break out of an excessively restrictive competitive framework and to approach the problem of technological change from different vantage points. The present paper will therefore look for clues to the process of technological change in several areas of the historical experience of the past century and a half or so. It will pose the question: have there been forces at work in recent history which have in fact pushed exploratory activity in specific directions? ${ }^{4}$ Nothing will be proven since historical examples by themselves prove nothing; hopefully, however, a beginning will be made toward a better understanding of some of the mechanisms which initiate and direct exploratory activities.

\section{I}

It will be argued first that, in looking for the origins of technological changes in the manufacturing sector, the technological level itself has been badly neglected. What will be said should not be confused with a crude form of technological determinism, where social, economic, and political changes are explained in terms of antecedent changes in technology. Rather, what is asserted is that technology is much more of a cumulative and self-generating process than the economist generally recognizes. Technological change, when approached from the point of view of economic theory, is likely to be treated as a realm which passively adjusts to the pressures and signals of economic forces, mediated through the market place and through factor prices in particular. The opposite danger, to which the following remarks are subject, is that they will be interpreted as saying that economic forces do not condition the direction in which technological changes move. Our position, then, is that the ultimate incentives are economic in nature; but economic incentives to reduce cost always exist in business operations, and precisely because such incentives are so diffuse and general they do not explain very much in terms of the particular sequence and timing of innovative activity. The trouble with the economic incentives to technical change, as an explanatory variable, is precisely that they are so pervasive. In the realm of pure theory, a decision maker bent upon maximizing profits under competitive conditions will pursue any possibility for reducing costs, regardless of which factor will be economized on. What forces, then, determine the directions in which a firm actually goes in exploring for new techniques? Since it cannot explore in all directions, what are the factors which induce it to strike out in

${ }^{4}$ In general, we would expect individual countries or regions to excel in innovations which constitute technical solutions to specific problems of special importance to them. Thus it is hardly surprising that pioneer America made major contributions to the improvement of the ax, or that contemporary Britain should assume world leadership in the development of techniques for the fully automatic landing of airplanes in dense fog. 


\section{Economic Development and Cultural Change}

a particular direction? Better yet, are there any factors at work which compel it to look in some directions rather than others?

In answering this question it may be necessary to modify the model of the maximizing firm to recognize explicitly real-world forces which constrain and otherwise influence its behavior. Within the realm of exploratory activities which may yield new, cost-reducing techniques, where does the firm place its resources? Some firms no doubt are able to take a very long time horizon and survey, with equanimity and fine impartiality, the whole spectrum of possibilities. But most firms-or at least most decision makers-are under pressure to undertake actions which promise a payoff in a relatively short time period and with at least most of the constraints imposed by the existing plant. They are confronted with the existing range of productive activities as an inevitable starting point. They are naturally led to search the technological horizon, as it were, within the framework of these current activities and to attack the most restrictive constraint. My primary point is that most mechanical productive processes throw off signals of a sort which are both compelling and fairly obvious; indeed, these processes when sufficiently complex and interdependent, involve an almost compulsive formulation of problems. These problems capture a large proportion of the time and energies of those engaged in a search for improved techniques.

Such signals have not, of course, been confined to the industrial sector of the economy. In agriculture, for example, the mechanization of reaping may be said to have been effectively "signalled" by the compelling and obvious need to harvest the wheat crop within a very limited number of days in order to prevent spoilage. ${ }^{5}$ Nevertheless, it seems to be a historical generalization, with which this paper is in fact much concerned, that such signalling has been more conspicuously effective in the industrial sector.

It will be argued that complex technologies create internal compulsions and pressures which, in turn, initiate exploratory activity in particular directions. These pressures operate at the plant level and also often within the components of the final product itself. The improved designs of automobile engines have led-through the achievement of higher speeds-to the invention of improved braking systems. The need for such systems-or perhaps one should say the penalty for failing to provide such a system along with a more powerful engine-was painfully obvious to all automotive engineers (if not to all drivers). Similarly, to someone constructing a hi-fi system it is obvious that the benefits of a high-quality amplifier are lost if it is attached to a low-quality loudspeaker. ${ }^{6}$ An understanding of these interdependencies may help us to

\footnotetext{
5 See the interesting article by Paul David, "The Mechanization of Reaping in the Ante-Bellum Midwest," in Industrialization in Two Systems, ed. Henry Rosovsky (New York: John Wiley \& Sons, 1966), pp. 3-39.

${ }^{6}$ Albert O. Hirschman and Charles E. Lindblom, "Economic Development, Research and Development, Policy Making: Some Converging Views," Behavioral Science (A pril 1962), p. 214.
} 
Nathan Rosenberg

understand better than we do the path and the process of technological change.

The notion of compulsive sequences will not be new to economic historians. Reference to the imbalances in the relation between machines is virtually de rigueur in any treatment of the English cotton textile industry in the eighteenth century (Kay's flying shuttle led to the need for speeding up spinning operations; the eventual innovations in spinning in turn created the shortage of weaving capacity which finally culminated in Cartwright's introduction of the power loom). ${ }^{\text {? }}$

In a sense the capital goods sector is always being bombarded with messages of the sort that say: "I expect to be able to earn a profit if I can produce a new device which will conform to certain specifications. But no machinery now exists which can produce such a device. Therefore you can earn a profit by devising and selling machines which will produce according to these specifications. Do so." The early prototype for this relationship was James Watt's protracted search for a cylinder bored to a minimum degree of accuracy in its diameter. The required degree of precision was eventually attained with the use of John Wilkinson's boring mill, and the commercial practicability of the steam engine really dates from the use of this mill in preparing cylinders. ${ }^{8}$ This backward linkage, to use Hirschman's terminology, has been an enormously important source of technical change in the Western world, and it can be argued that a responsive machinery-producing industry has been the key to successful industrialization. My concern, however, is not primarily with the historical responsiveness of certain supply factors but with the manner in which the demand for new techniques emerges and is perceived. ${ }^{9}$

${ }^{7}$ Paul Mantoux, The Industrial Revolution in the Eighteenth Century (London, 1948), pp. 211-13, 244-51; H. J. Habakkuk, American and British Technology in the Nineteenth Century (New York: Cambridge University Press, 1962), p. 134. For a recent more rigorous formulation by an economic historian, see J. R. T. Hughes, "Foreign Trade and Balanced Growth: The Historical Framework," American Economic Review Papers and Proceedings (May 1959), pp. 330-37. See also Tibor Scitovsky, "Growth-Balanced or Unbalanced?" in The Allocation of Economic Resources, by M. Abramovitz et al. (Stanford, Calif.: Stanford University Press, 1959), esp. pp. 215-16.

8 The incredible improvisations which Watt resorted to, before availing himself of Wilkinson's machinery, are suggested in the following: "The close fitting of the piston in the cylinder, which did not so greatly matter in the Newcomen engine, was essential to the proper working of Watt's. For want of an accurate boring-machine, the cylinder of his first engine was made of tin and hammered to shape against a hard-wood block; the gaps between piston and cylinder were sealed as far as possible with felt, paper, oiled rags, and the like" (K. R. Gilbert, "Machine Tools," in A History of Technology, ed. Charles Singer et al. (London: Oxford University Press, 1958), 4:421.

${ }^{y}$ From this point of view the critical question is why some economies have been capable of a creative response to this sort of demand while others have not been so capable. On the role of the machine tool industry as a creator and diffusor of new techniques, see Paul Strassmann, "Interrelated Industries and the Rate of Technological 


\section{Economic Development and Cultural Change}

\section{II}

Let us consider some historical episodes. In the early 1890s, at the beginning of the bicycle craze, the machining of bicycle-wheel hubs posed a serious production problem. Forming tools, which previous to 1890 had been applied to metals of soft composition, such as the caps of salt and pepper boxes, were successfully applied to hardened metals in the shaping of the outside of the wheel hubs. However, this use of the forming tool created an imbalance between the operations carried on for the outside and the inside of the hub. Since the forming tool now worked more rapidly on the outside of the hub than the conventional drills worked on the inside, it was not possible to derive the fullest gains from the use of the forming tool. This imbalance was eventually corrected by the introduction of the oil-tube drill. This drill had an oil channel leading to or near the point, and it made possible the lubrication and cooling of cutting edges as well as the removal of chips, and therefore speeded up drilling operations. In doing so, the oil-tube drill corrected the initial imbalance and brought about a closer synchronization between the operations on the outside and the inside of the hub. ${ }^{10}$

A similar sort of technical imbalance between interdependent processes led to important improvements in the internal structure of the Bessemer converter. The early Bessemer converters required a considerable amount of expensive, auxiliary equipment. This equipment was utilized only a small percentage of the time, partly because the bottom of the converter wore out, due to the extreme temperatures of the process, after one to three heats. At that point the converter had to be allowed to cool so that a man could climb inside and repair the lining. Alexander Holley addressed himself directly to correcting this imbalance by devising ways of speeding up the use of the converter. His eventual solution was a removable shell for the bottom of the converter which made it unnecessary to let the converter cool and therefore led to a considerable saving of time and reduction in costs. ${ }^{1}$

According to Bessemer's own testimony, the search activity which led

Change," Review of Economic Studies (October 1959), pp. 16-22; and Nathan Rosenberg, "Technological Change in the Machine Tool Industry, 1840-1910," Journal of Economic History (December 1963), pp. 414-43. Some of the historical examples in the next section have been drawn from the latter paper.

${ }^{10}$ Neither the forming tool nor the oil-tube drill (which had previously been used in drilling gun barrels) had originated in the bicycle industry. However, both had previously been used for only very limited purposes, and their application to new kinds of uses in bicycle production was directly responsible for their much wider industrial application. The shaping of bicycle hubs was one of the first, if not in fact the first, use of the forming tool on hardened metals (see Rosenberg, pp. 435, 438-39; Twelfth Census of the United States [1900], 10:385-88; Fred Colvin, Sixty Years with Men and Machines [New York: McGraw-Hill Book Co., 1947], pp. 88-89).

11 Peter Temin, Iron and Steel in Nineteenth Century America (Cambridge, Mass. M.I.T. Press, 1964), pp. 135-36. 
Nathan Rosenberg

to the development of the Bessemer process of steel production was itself initiated by a problem Bessemer confronted which conforms precisely to what is being called here a technical imbalance. Bessemer stated in his autobiography that his attention was directed to the subject of artillery by the outbreak of the Crimean War in 1854. He developed a new gun of superior power, capable of firing a heavy, elongated projectile. To his dismay, however, he concluded that the gun could not be safely fired if it were constructed of the standard cast iron employed in artillery pieces. The Bessemer process was the product of Bessemer's search for a superior metal which would make his newly designed gun practicable by withstanding the severe strains imposed by the heavy weight of the projectiles. ${ }^{12}$

The introduction of high-speed steel into the machine tool industry constitutes a major example of technological imbalance. High-speed steel is a steel alloy (combined with tungsten, vanadium, and chromium) which raised enormously the red hardness of cutting tools ${ }^{13}$ and therefore made it possible to remove metal by cutting at dramatically higher speeds and also by taking heavier cuts in the metal. High-speed steel was first developed by Frederick W. Taylor and his associates and exhibited in operation at the Paris Exposition of 1900. "At that exhibition they exhibited tools made of this steel, in use in a heavy and powerful lathe, taking heavy cuts at unheard of speeds- 80 , 90 or 100 feet per minute, instead of the 18 to 22 feet per minute that previously had been the maximum for heavy cuts in hard material." ${ }^{14}$ It turned out, however, that it was impossible to take advantage of higher cutting speeds with machine tools designed for the older carbon steel cutting tools because they could not withstand the stresses and strains or provide sufficiently high speeds in the other components of the machine tool. As a result, the availability of high-speed steel for the cutting tool quickly

12 Sir Henry Bessemer, F.R.S.: An Autobiography (London: Offices of "Engineering," 1905), pp. 131-36. Referring to his experimental tests of the gun with the cooperation of the French government at Vincennes, Bessemer concludes: "The experiments at Vincennes took place on or about the 22nd December, 1854, and before the close of that year I found myself once more at Baxter House, busy with plans for the production of an improved metal for the manufacture of guns, which improvement in the quality of the iron I proposed to effect by the fusion of steel in a bath of molten pig-iron in a reverberatory furnace. I soon determined on the form of furnace, and applied for a patent for my "Improvements in the Manufacture of Iron and Steel," which was dated as early as January 10th, 1855 - that is, within three weeks after the experiments in the Polygon at Vincennes" (ibid., pp. 136-37).

13 "Tool steels of the older type retained their hardness up to only $350^{\circ} \mathrm{F}$, whereas high-speed steels show no appreciable softening up to $1100^{\circ}$ " (Carl J. Oxford, "One Hundred Years of Metal Cutting Tools," Centennial of Engineering 1852-1952 [Chicago: Museum of Science and Industry, 1953], p. 346).

14 “Metal-working Machinery," Special Reports of the Census Office (1905, Part IV), p. 232 . 
Nathan Rosenberg

\section{Economic Development and Cultural Change}

generated a complete redesign in machine tool components-the structural, transmission, and control elements. As one machine tool authority put it: "During the first decade of the 20th century we see high-speed steel revolutionizing the lathe-as it does all production machine tools. Beds and slides rapidly become heavier, feed works stronger, and the driving cones are designed for much wider belts than of old. The legs of big lathes grow shorter and shorter, and finally disappear as the beds grow down to the floor. On these big machines massive tool blocks take the place of tool posts, and multiple tooling comes into vogue."15

The final effect of this redesigning which was initiated by the use of high-speed steel in cutting tools was to transform machine tools into much heavier, faster, and more rigid instruments which, in turn, enlarged considerably the scope of their practical operations and facilitated their introduction into new uses. Much of the progress in machine tools resulted from the generation of imbalances between the machine itself and the cutting tool. Improvements in the cutting tool required machines of greater strength, rigidity, capacity to withstand stress, etc. Improvements in the design and operation of the machines, in turn, were useless without improvements in the properties of the cutting tool. ${ }^{16}$

In this exploratory activity, however, which was initiated to accommodate the new requirements of high-speed steel, inventions were made which went far beyond the need merely to make such accommodations. The need to adapt speeds and feeds to the enlarged cutting capacity of the tool was a major stimulus to the development of new speed-changing devices. For example, the cone pulley, a primitive device for altering the speed of the machine tool in accordance with the requirements of the work in hand, was replaced by much more sophisticated gear-change devices which enabled the operator to vary the speed merely by shifting a lever. ${ }^{17}$

This "over-shooting" of the mark is, of course, characteristic of

${ }^{15}$ Guy Hubbard, "Metal-working Plants," Mechanical Engineering 52 (1930): 411. Cf. also H. I. Brackenbury, "High-Speed Tools and Machines to Fit Them," Proceedings, Institution of Mechanical Engineers 63 (1910): 929-51.

${ }^{16}$ A similar set of imbalances and compulsive sequences, with very similar results, has occurred more recently in connection with the introduction of cemented carbide tools and ceramic tools. See, e.g., The American Society of Mechanical Engineers, Manual on Cutting of Metals: Single-point Lathe Tools (New York: ASME, 1939), pp. 24-25, and the numerous articles on ceramic tools in the Tool Engineer, beginning in 1955.

17 Special Reports of the Census Office (1905), p. 233. In an important article Einstein stated: "Meanwhile high-speed steel had appeared on the market, which revolutionized the machine-tool industry. Cutting speeds of the various tools could materially be increased with this new material, and at the same time higher rates of traverse of tool or work could be used. This resulted in the development of the so-called single-pulley machine which adopted the positive-gear-change mechanism of the feedbox and used it for the drive of the machine. These new types of machines, heavier in structure, with a 
Nathan Rosenberg

exploratory activities. Such activities are undertaken in response to certain kinds of stimuli, and although the stimuli must presumably exceed some minimum magnitude in order to be perceived and acted upon, the "size" of the discovery need bear no systematic relationship to the "size" of the initial stimulus.

In the case of machine tools, the interdependence is of four component parts. In addition to the cutting tool itself there are:

1. Structural or frame elements whose function it is to carry or support work and tool.

2. Transmission elements which give the work or tool, or both, movements for shaping the work to be produced.

3. Control elements for both adjusting the structural elements relatively to each other and controlling the function of the transmission for moving either tool or work or both. ${ }^{18}$

This sequence-changes in one component of an interdependent system creating a stimulus for changes elsewhere in this system - has been a highly fruitful source of technical change in the machine tool industry. Awareness of imbalances between components has continually led to an exploration of possibilities for corrective action whose eventual result was major improvements in productivity. The imbalance between high-speed cutting tools and the lathe was exactly duplicated in the relationship between milling cutters and milling machines from the 1880 s to the early years of the twentieth century. Thus Woodbury tells us:

De Leeuw's analysis had shown that the cutters of the time were not as strong as the machines that were driving them and therefore gave out long before the maximum power of the machine was reached. On this basis Cincinnati Milling Machine Company designed a new face mill, later marketed by Union Twist Drill Company, which increased the metal removal per horsepower by $50 \%$. Further experiments on a larger scale were carried out by A. L. De Leeuw at Cincinnati Milling Machine Company which led to the design of wide spaced cutters as more durable and more efficient in removing metal. ${ }^{19}$

A set of interrelated changes entirely analogous to those following upon the introduction of high-speed steel on the lathe may also be observed in the history of the grinding machine. There the sequence of technical

positive drive to the work and the tool, successfully took up the battle with high-speed steel, and in a large number of cases new shapes of tools had to be developed to utilize successfully the full cutting capacity of these new machines" (S. Einstein, "Machine-Tool Milestones, Past and Future," Mechanical Engineering [November 1930], p. 960).

18 Einstein, p. 959.

19 Robert S. Woodbury, History of the Milling Machine (Cambridge, Mass.: M.I.T. Press, 1960), p. 80. 
Nathan Rosenberg

\section{Economic Development and Cultural Change}

imbalances and their systematic correction and "overcorrection" was triggered by the introduction of artificial abrasives in the construction of the grinding wheel. The sequence culminated in the conversion of the grinding machine from an instrument used only to perform finishing operations on components which had acquired their basic shapes on a lathe, to a machine performing heavy production operations on the automobile. Indeed, the grinding machine in this form became indispensable to the emerging automobile industry because it provided the only way, at the time, of precision machining of the strong, light alloy steels which played such a prominent part in automobile components. ${ }^{20}$

The history of technology is replete with examples of the beneficent effects of this sort of imbalance as an inducement for further innovation. To venture somewhat farther afield, the history of military technology provides numerous examples of improvements in weaponry resulting from the continuous rivalry between offensive and defensive weapons. The contemporary race between the development of missiles and antimissiles is merely the latestand most destructive-stage of a compulsive rivalry which has been going on for many centuries. A classic case occurred with the development of highpowered, rifled ordnance in the 1850 s, in large measure as a result of the work of Joseph Whitworth and William Armstrong. The great increase in the destructive power of offensive weapons led to the application of armored plate to ships to protect them against such weapons. It was out of this interplay that, in thirty or forty years, the modern warship was developed. ${ }^{2}$ Even a hundred years ago, however, this rivalry was recognized as something which was already a time-honored process. An article in Mechanics Magazine in 1867 concluded its evaluation of the current experiments involving new armored plates by stating: "It appears to be the old story over again; no sooner is a gun or projectile produced which carries everything before it, than a target is devised by which it can be stopped." 22

Technical imbalances leading to changes in complementary processes may be clearly observed even in medieval siege machinery. After successive

${ }^{20}$ Robert S. Woodbury, History of the Grinding Machine (Cambridge, Mass.: M.I.T. Press, 1959), esp. pp. 73-108; Rosenberg, pp. 435-38.

${ }^{21}$ See, e.g., Edward J. Reed and Edward Simpson, Modern Ships of War (New York, 1888); or the article "Battleships" in Encyclopaedia Britannica.

22 “Ordnance versus Armour,” Mechanics Magazine, n.s. 17 (March 15, 1867): 157. A recent book summarizes the resulting changes in the British Navy as follows: "The guns used at Inkerman and Balaclava did not differ greatly from those which had been used at Torres Vedras or Waterloo; and in the fleet which sailed to the Crimea, the standard armament of the line-of-battle ship was a 32-pounder smoothbore, firing a shot with a velocity of 1,600 feet per second, mounted upon a crude wooden carriage with a recoil controlled by the friction of large wooden axles, and served by a crew so large that they practically hid their unwieldy little weapon from sight. ... By the late Eighties all this was changed. The guns were changed; as early as the Seventies Britain was building a 


\section{Nathan Rosenberg}

improvements in the trebuchet, the medieval artillery piece, it became apparent in the thirteenth century that further improvements in accuracy could not be achieved unless the projectile itself was altered.

... the very fact that the power of a trebuchet could be so nicely regulated impelled Western military engineers to seek even greater exactitude in artillery attack. They quickly saw that until the weight of projectiles and their friction with the air could be kept uniform, artillery aim would still be variable. As a result, as early as 1244 stones for trebuchets were being cut in the royal arsenals of England calibrated to exact specifications established by an engineer: in other words, the cannon ball before the cannon. ${ }^{23}$

Part of the reason for the effectiveness of technological disequilibria in inducing innovations is that they involved compulsive sequences. The relationship among components was usually such that some imbalance had to be corrected before an initial innovation could be fully exploited. Such a situation therefore continually directed the attention of technically competent personnel to the solution of problems of obvious practical importance. ${ }^{24}$

16-inch 80-ton gun-an almost incredible weapon. The ships to carry such guns had in turn to be changed out of recognition. By the late Eighties we have the Hood, 'a turret ship with eight redoubts' mounting four 67-ton guns and ten 6-inch quick-firing guns, eighteen smaller quick-firing guns and eight machine guns. The powerful guns, in turn, had called for thicker armour, 'till in 1881 the Inflexible carried, in places, 24inch plates.' Such weights of armour could obviously not be carried along the entire length of a ship, and so had, in turn, led to the collecting of all the vital parts of warships into a 'citadel'; it was these massive citadels which gave the new kind of warship its characteristic appearance. In the years between 1858 and 1888 the wooden-wall broadside navy had gone for ever: the Navy of 1858 was still the navy that had fought at Trafalgar; the Navy of 1888 was already the navy that fought at Jutland" (J. D. Scott, Vickers: $A$ History [London: Weidenfeld \& Nicolson, 1962], p. 23).

23 Lynn White, jr., "The Act of Invention," in The Technological Order, ed. Carl Stover (Detroit: Wayne University Press, 1963), p. 111. Elsewhere White has observed that "the new violence of the lance at rest called for heavier armour, which in turn produced the crossbow as an 'anti-tank gun' " (Lynn White, jr., in Scientific Change, ed. Alistair C. Crombie [New York: Basic Books, 1963] . p. 278). The imbalance relationship, of course, sometimes terminates with the complete triumph of one component in the relationship over the others. In the sixteenth century, e.g., the armorer fought a frequently ingenious and often highly decorative but inevitably losing battle with firearms, since significant protection against such weapons required intolerably heavy armor. It is reported that, even without the leg pieces, the armor made for the duc de Guise in 1588 weighed over 100 pounds. "By the mid-seventeenth century infantry commonly wore nothing more formidable than a leather jerkin, and cavalry only an iron cuirass" (A. R. Hall "Military Technology," in A History of Technology, ed. Charles Singer et al. [London: Oxford University Press, 1957], 3:353).

24 Why, one might be inclined to ask, have such disequilibria been most important 


\section{Economic Development and Cultural Change}

\section{III}

The apparent recalcitrance of nineteenth-century English labor, especially skilled labor, in accepting the discipline and the terms of factory employment provided an inducement to technical change which was in many ways analogous to the technical disequilibria discussed so far. The most important point is that the threat of worker noncompliance-in the last resort, strikes-served as a powerful agent in focusing the attention of decision makers on obvious and major threats to their profit positions. Here again it may be said that employers had a general, diffuse economic incentive to reduce costs, regardless of which factor inputs were being economized on. But it was also obvious that the labor input was the one which posed the greatest threat, in that its services were likely to be withheld at times and in ways which constituted a serious threat to a firm's profit prospects. The threat of such withdrawals, then, was a powerful force in directing energies in a search for labor-saving machines.

The view was widely expressed in nineteenth-century England, especially in the period 1820-60, that strikes were a major reason for innovations. Contemporary observers who agreed on little else, who were as far apart in their ideological biases and commitments as, say, Karl Marx and Samuel Smiles, were in complete accord on this point. We have, moreover, the evidence of numerous inventors themselves, who testified that they undertook the search process which led to a particular invention as the result of a strike or the threat of a strike.

In the Poverty of Philosophy, Marx stated:

In England, strikes have regularly given rise to the invention and application of new machines. Machines were, it may be said, the weapon employed by the capitalists to quell the revolt of specialized labour. The self-acting mule, the greatest invention of modern industry, put out of action the spinners who were in revolt. If combinations and strikes had no other effect than that of making the efforts of mechanical genius react against them, they would still exercise an immense influence on the development of industry. ${ }^{25}$

in areas dominated by a fairly sophisticated mechanical technology? Why have they not been equally important, say, in agriculture? This is a big question. Part of the answer, I would suggest, is that the person receiving such signals in agriculture - the farmer-is not, himself, competent by training or occupational experience to evaluate them in a creative way. In the industrial sector there has been a continuous and direct confrontation between technical problems and personnel with the competence to solve them, whereas many of the problems of agriculture have had to await the development of specialized institutions (e.g., land-grant colleges) and specialized professions with the requisite skills-genetics, soil chemistry, and, of course, mechanical technology as well.

25 Karl Marx, The Poverty of Philosophy (Moscow, n.d.), p. 161. Earlier in the same work Marx had stated: “... from 1825 onwards, almost all the new inventions were the result of collisions between the worker and the employer who sought at all costs to 
Nathan Rosenberg

In Capital, Marx stated: "It would be possible to write quite a history of the inventions, made since 1830, for the sole purpose of supplying capital with weapons against the revolts of the working-class." ${ }^{26}$ Here again he asserted that the most important of these inventions was Richard Roberts's self-acting mule, because it "opened up a new epoch in the automatic system." $" 27$ Roberts's mule was invented in 1825 as the result of a strike on the part of the skilled and highly independent mule-spinners. A delegation of Manchester cotton manufacturers appealed to Roberts to help them in their desperate plight, and Roberts's inventive skill brought forth the self-acting mule. This famous episode was dwelt upon at some length, not only by Marx, but by Smiles $^{28}$ and Ure, who concluded his discussion by stating, in one of his inimitable didactic excursions, "that when capital enlists science in her service, the refractory hand of labour will always be taught docility." 29

Another of Roberts's important inventions, the so-called Jacquard punching machine, owed its origin to somewhat similar circumstances. ${ }^{30}$

depreciate the worker's specialized ability. After each new strike of any importance, there appeared a new machine" (p. 134).

${ }^{26}$ Karl Marx, Capital (Moscow, 1961), 1:436. $\quad{ }^{27}$ Ibid.

28 Samuel Smiles, Industrial Biography (London: John Murray, 1908), pp. 267-70. Smiles called the self-acting mule "one of the most elaborate and beautiful pieces of machinery ever contrived" (p. 267).

29 Andrew Ure, Philosophy of Manufactures (London, 1835), p. 368. Cf. Gaskell, who stated: "These unions, which have ramified throughout the entire factory labourers, are sources of great embarrassment to the master, whose energy, activity, and capital, are more or less at their mercy. He cannot, however, dissolve them by force; and the knowledge which the men have of the cheapening power of machinery keeps them together. If the master cannot overcome them by force, he has another and a sure, though gradual agent of destruction in the workshop of the machinist; and it is this that he is wielding with silent but irresistible force, which will free him from his adult and combined labourers.... It is impossible to deny that the men have accelerated the advance of the mighty agent which is to destroy them" (P. Gaskell, Artisans and Machinery [London, 1836] , p. 349). Nasmyth, who commented frequently on the dilatoriness of labor, wrote enthusiastically of self-acting tools: "They were always ready for work, and never required a Saint Monday" (James Nasmyth: An Autobiography, edited by Samuel Smiles [London, 1883] , p. 307). See also H. W. Dickinson, "Richard Roberts, His Life and Invention," Transactions of the Newcomen Society 25 (1945-47): 127. A sales agent for the McCormick reaper in the 1850s stated that it was the purpose of his work to "place the farmer beyond the power of a set of drinking Harvest Hands with which we have been greatly annoyed" (William T. Hutchinson, Cyrus Hall McCormick, vol. 1: Seed-Time, 1809-1856 [New York: Century Co., 1930], p. 470). As quoted by Paul David, "Mechanization of Reaping in the Ante-Bellum Midwest," in Industrialization in Two Systems, ed. H. Rosovsky (New York: John Wiley \& Sons, 1966), p. 18.

30 "The origin of this invention was somewhat similar to that of the self-acting mule. The contractors for the Conway Tubular Bridge while under construction, in 1848, were 


\section{Economic Development and Cultural Change}

Marx had pointed out that "W. Fairbairn discovered several very important applications of machinery to the construction of machines, in consequence of strikes in his own workshops." ${ }^{\prime 1}$ Fairbairn himself described how his riveting machine had originated with a

stoppage of a part of the works at Manchester by a strike of the boiler-makers. For some time previously we had been busily engaged in the construction of boilers, and nothing could have been more injurious than the stoppage of the works at such a time. I remonstrated with the men, but without effect, and perceiving no chance of coming to terms in any reasonable time, I determined to do without them, and effect by machinery what we had heretofore been in the habit of executing by manual labour. ${ }^{32}$

After some experimentation, with the assistance of one of his employees, Fairbairn devised a riveting machine for which a patent was procured in 1837.

The new machine effected a comple te revolution in boiler-making and riveting, and has substituted the rapid and noiseless work of compression for the eternal din of the hammer; besides making the work infinitely superior in quality and strength.

The introduction of the riveting machine gave great facilities for the despatch of business. It fixed, with two men and a boy, as many rivets in one hour as could be done with three men and a boy in a day of twelve hours on the old plan; and such was the expedition and superior quality of the work, that in less than twelve months the machine-made boilers were preferred to those made by hand, in every part of the country where they were known. ${ }^{33}$

greatly hampered by combinations amongst the workmen, and they despaired of being able to finish the girders within the time specified in the contract. The punching of the iron plates by hand was a tedious and expensive as well as an inaccurate process; and the work was proceeding so slowly that the contractors found it absolutely necessary to adopt some new method of punching if they were to finish the work in time. In their emergency they appealed to Mr. Roberts, and endeavored to persuade him to take the matter up. He at length consented to do so, and evolved the machine in question during his evening's leisure-for the most part while quietly sipping his tea. The machine was produced, the contractors were enabled to proceed with the punching of the plates independent of the refractory men, and the work was executed with a despatch, accuracy, and excellence that would not otherwise have been possible" (Smiles, Industrial Biography, pp. 271-72).

31 Marx, Capital, p. 436.

32 The Life of Sir William Fairbairn, Bart., edited and completed by William Pole (London, 1877), p. 163.

${ }^{33}$ Ibid., p. 164. In 1873, shortly before his death, Fairbairn wrote: "The introduction of new machinery and the self-acting principle owed much of their efficacy and ingenuity to the system of strikes, which compelled the employers of labour to fall back upon their own resources, and to execute, by machinery and new inventions, work which was 
Nathan Rosenberg

Babbage (and others) attributed the invention of the system of grooved rollers for rolling skelps for musket barrels to a strike of the gun-skelp forgers who were, in substantial measure, superseded by the invention. He points out also that the technique of welding the skelps into a finished gun barrel was perfected as a result of difficulties encountered with a combination of workers. ${ }^{34}$

The uncertainties which the supply of labor posed in the British gunmaking industry eventually led to the first large-scale borrowing of American technology by the Old World. For the British government's demand for firearms was not only highly erratic but also, in time of national emergency, highly inelastic. Since military firearms, up to the 1850 s, were produced entirely by skilled craftsmen whose supply was certainly highly inelastic in the short run, the entry of the government into the market almost invariably led to strikes or threats of strikes unless wages were raised substantially. This situation resulted in an almost complete breakdown in supplies of firearms on the eve of the outbreak of the Crimean War in 1854. In its determination to free itself from what it regarded as an intolerable dependence on a small number of skilled workers, the British government sent a commission to the United States to examine American gunmaking machinery. This commission purchased large quantities of machines which were set up at the Enfield Arsenal. The purchase marked the introduction of American mass-production technology into Europe, where the system was long referred to as the "American System of Manufacturing.", 5

formerly done by hand" (ibid., pp. 419-20). Cf. also p. 46, and Mechanics Magazine 32 (1840): 190. An illustration as well as description of the machine appeared in Official Description and Illustrated Catalogue of the Great Exhibition of the Works of Industry Of All Nations (London, 1851), pp. 286-87.

34 Charles Babbage, On the Economy of Machinery and Manufactures (London, 1835), pp. 298-300. Cf. Richard Prosser, Birmingham Inventors and Inventions (Birming ham, 1881), p. 86. Goodman states: "The invention of making gun barrels by means of grooved rolls is due to a Birmingham manufacturer of the name of Osborne. It was on the occasion of a strike of the barrel welders that he was led to make the experiment. He was not allowed to introduce his system without opposition, for no sooner were his rolls set to work than twelve hundred barrel welders, each armed with his forge hammer, proceeded to the private residence of Mr. Osborne, in the Stratford Road, threatening its destruction. The military were called out before the disturbance could be quelled, and for many days afterwards a guard was placed over the mill in which the work was carried on" (John D. Goodman, "The Birmingham Small Gun Trade," in Birmingham and the Midland Hardware District, ed. S. Timmins [London, 1866], p. 389).

35 "Report of the Committee on the Machinery of the U.S.A.," Parliamentary Papers (1854-55), vol. 50. The history of the British government's troubled relationship with the gun trade is exhaustively ventilated in "Report of the Select Committee on Small Arms," Parliamentary Papers (1854), vol. 18. In its final report, the committee conveniently summarized Nasmyth's views as follows: “Mr. Nasmyth, the well-known inventor 


\section{Economic Development and Cultural Change}

Many contemporaries cited the long engineers' strike of 1851 as an important direct cause of the introduction of new, labor-saving techniques.

Mr. Nasmyth, in his evidence before the Trades Unions Commissioners, described very graphically how the long strike of 1851 made him anxious to develop to the utmost the use of labour-saving machinery. "The great feature," he said, "of our modern mechanical improvement has been the introduction of self-acting tools. All that a mechanic has to do, and which any lad is able to do, is, not to labour, but to watch the beautiful functions of the machine. All that class of men, who depended upon mere dexterity, are set aside altogether. I had four boys to one mechanic. By these mechanical contrivances I reduced the number of men in my employ, 1,500 hands, fully one half. The result was that my profits were much increased."36

Finally, we may cite Smiles's observations on the impact of strikes in his discussion of Nasmyth's experiences.

Notwithstanding the losses and suffering occasioned by strikes, Mr. Nasmyth holds the opinion that they have on the whole produced much more good than evil. They have served to stimulate invention in an extraordinary degree. Some of the most important labour-saving processes now in common use are directly traceable to them. In the case of many of our most potent self-acting tools and machines manufacturers could not be induced to adopt them until compelled to do so by strikes. This was the case with the self-acting mule, the wool-combing machine, the planing machine, the slotting machine, Nasmyth's steam arm, and many others. ${ }^{37}$

It would be easy to multiply examples. ${ }^{38}$ Such multiplication, however, would add nothing further to our point, which is simply to suggest that

of the steam-hammer, considers the systematic introduction of machinery in to the gun trade to be highly desirable.... He considers that in the gun trade, the masters are in a state of dependence upon the skilled workmen, from which they can only be emancipated by the substitution of machinery for hand labour" (p. vi).

${ }^{36}$ Thomas Brassey, Work and Wages (New York, 1883), pp. 129-30. See also the testimony of John Anderson, "Report from the Select Committee on Small Arms," Q. 356. Brassey was strongly committed to the proposition that the high price of labor is a major stimulus to inventive activity. Chapter 5 of Work and Wages is titled "Dear Labour Stimulates Invention." Conversely "the cheap labour at the command of our competitors seems to exercise the same enervating influence as the delights of Capua on the soldiers of Hannibal" (ibid., p. 142).

37 Smiles, Industrial Biography, pp. 294-95.

38 Such as "the adoption of the Fourdrinier machine after 1800 by English paper manufacturers was due largely to their desire to break the power of skilled labour in the industry" (Habakkuk [see n. 7 above], p. 153). See also D. C. Coleman, The British Paper Industry (London: Oxford University Press, 1958), pp. 258-59. 


\section{Nathan Rosenberg}

strikes or fear of strikes have served, historically, as a powerful agent for directing the search for new techniques in a particular direction. The preoccupation with substituting capital for labor (especially skilled labor) was more than just a matter of wage rates. Perhaps even more important was the great nuisance value of strikes. In part at least, entrepreneurial behavior must be understood in terms of an aversion to the uncertainties presented by strike possibilities whose disruptive effects were regarded as intolerable intrusions into the domain of managerial decision making and responsibility. ${ }^{39}$

\section{IV}

There is a third category of mechanisms which seems to have been important, historically, in providing successful inducements to technical change. Perhaps the most general way of expressing it is that an accustomed source of supply was, for some reason, cut off or drastically reduced, causing major disruption due to the unavailability either of alternative sources of supply or of satisfactory substitutes. The most common cause of such disruption, of course, has been the outbreak of war. In each case the imposition of a previously nonexistent contraint led to a search activity out of which a satisfactory or superior substitute, or more productive process, eventually emerged.

Thus, France's early commercial leadership in the synthetic alkali industry, developed upon the Leblanc process, owed a great deal to the fact that France was cut off from its supplies of Spanish barilla during the Napoleonic Wars. ${ }^{40}$ An eminent observer, Robert Owen, said more generally in describing the effect of the Napoleonic Wars: "The want of hands and materials created a demand for and gave great encouragement to new mechanical inventions and chemical discoveries, to supersede manual labour in supplying the materials required for warlike purposes." 41

The cutting off of American cotton supplies to Britain during the

${ }^{39}$ The point about uncertainties is, of course, in principle a general one. Under nineteenth-century conditions, it was the disruption in their labor supply which seems to have constituted the most serious threat to entrepreneurs who were concerned with maintaining the continuity of their productive operations. But uncertainties about power failure may persuade an entrepreneur to avoid an electricity-using process, or uncertainties over the supply of water may militate against a reliance upon water power. In fact, there were many instances in the nineteenth century when the erratic variations in water supply (partly, of course, a seasonal phenomenon) were crucial in inducing mill owners to introduce steam-power.

40 David Landes, "Technological Change and Development in Western Europe, 1750 1914," in The Cambridge Economic History of Europe, ed. M. M. Postan and H. J. Habakkuk (London: Cambridge University Press, 1965), 6: 340-41: See also L. F. Haber, The Chemical Industry during the Nineteenth Century (London: Oxford University Press, 1958), chaps. 1 and 2; T. C. Barker, R. Dickinson, and D. W. F. Hardie, "The Origins of the Synthetic Alkali Industry in Britain," Economica (May 1956), pp. 158-71.

${ }^{41}$ Life of Robert Owen, p. 171, as quoted in Habakkuk, p. 135. 


\section{Economic Development and Cultural Change}

American Civil War and the resulting cotton famine apparently served as an important inducement to technical change in British textiles. Although these changes included, as one would expect, methods which, by reducing waste, economized on the cotton input, the changes were by no means confined to such economies. ${ }^{42}$ During World War I, the Germans were deprived of their imports of Chilean nitrates by the English blockade, and in their efforts to find a substitute they perfected the nitrogen fixation process. ${ }^{43}$ On the other hand, the cessation of trade with Germany also resulted in the cutting off of U. S. imports of German chemical products, particularly dyes. By the end of the war the United States had developed a dye industry of substantial proportions. ${ }^{44}$ Finally, as is well known, the cutting off of the supply of southeast Asian natural rubber due to Japanese occupation early in the Second World War was responsible for advancing the research activity which culminated in the emergence of the American synthetic rubber industry. ${ }^{45}$

In all of these cases, of course, a major deterrent to most innovationsignorance of the possible size and nature of the market-was nonexistent. The market for the commodity was well established, and the "message" to potential suppliers of substitutes was unmistakably clear. It was further dramatized by the abruptness with which supplies were terminated, the sharpness of the domestic rise in price, and, in some cases, the strategic importance of the commodity.

Although the instances cited have in common the impact of war

42 Marx, Capital, 1:433-36. Writing only a few years after the events, Marx exclaimed: "But who, in 1860, the Zenith year of the English cotton industry, would have dreamt of the galloping improvements in machinery, and the corresponding displacement of working people, called into being in the following 3 years, under the stimulus of the American Civil War?" (p. 433). The examples Marx subsequently cited include techniques which obviously economized on capital and labor inputs more than they did on cotton (cf. Habakkuk, p. 159). Figures on cotton prices and the volume and sources of cotton imports immediately before, during, and after the cotton famine may be found in Thomas Ellison, The Cotton Trade of Great Britain (London, 1886), p. 91.

43 Jesse Markham, The Fertilizer Industry (Nashville, Tenn: Vanderbilt University Press, 1958), p. 98.

44 George W. Stocking and Myron W. Watkins, Cartels in Action (New York: Twentieth Century Fund, 1946), chap. 9.

45 Although wartime situations and military requirements have thus been a most important historical force, one should nevertheless avoid overstatement. The following quotation from Bernal is, surely, a gross exaggeration: "Science and warfare have always been most closely linked; in fact, except for a certain portion of the nineteenth century it may fairly be claimed that the majority of significant technical and scientific advances owe their origin directly to military or naval requirements" (J. D. Bernal, The Social Function of Science [New York: Macmillan Co., 1939], p. 165). For a forceful statement of an opposing view, see John Nef, War and Human Progress (New York: Russell \& Russell, 1950). 
Nathan Rosenberg

in cutting off users from traditional suppliers, such need not be the case. The attempt of the Japanese, after occupying Formosa in 1895, to exploit that island's virtual monopoly of the supply of natural camphor was a powerful stimulus to the search for a synthetic process, which was eventually perfected. ${ }^{46}$

Even an act of legislation that imposes a constraint may lead to exploratory activities which eventually confer an advantage to those who were constrained. Thus, Keirstead states that "the Swedish law against stream pollution forced Swedish producers of chemical pulps to work out means of utilizing waste liquors. Waste liquors from the sulphate process are ordinarily recovered in Canada, but waste sulphite liquor is not. The recovery process of waste sulphite liquor in Sweden has consequently given the Swedish sulphate producers an advantage over their Canadian and American competitors." 7 Similarly, James Watt's invention of the epicyclic (or "sun and planet") gear for the conversion of reciprocating into continuous rotary motion owed much to his apprehension over possible litigation. Watt rejected the more obvious alternative of a crank mechanism for this purpose because of the possibility that it may have been covered by the recent patent by James Pickard of Birmingham. ${ }^{48}$

The building of the tubular railroad bridge across the Menai Straits in the 1840 s is a further interesting example of the beneficient-and quite unanticipated-effects of the introduction of a constraint. Due to restrictions imposed by the admiralty (which was concerned with the headroom and width that the bridge would leave for navigation) on the form and size of bridge which it would allow to span the straits, an entirely new technique of bridge building was invented. The solution of the problems involved in building the bridge subject to admiralty constraints resulted in fundamental advances in knowledge concerning the structural properties of iron-resistance of beams and plates, strength of girders, compression and tensile strengths, etc. This new knowledge had a wide range of immediate applications, not only in other bridges, but in the construction of cranes, ships, multistorey buildings, steam engines-indeed, wherever iron was used as a building material. ${ }^{49}$

All of this, admittedly, brings us perilously close to the proposition that "new constraints are good for you," which is in some ways analogous to a

${ }^{46}$ William Haynes, This Chemical Age (New York: A. A. Knopf, 1945), pp. 164-67.

${ }^{47}$ B. S. Keirstead, The Theory of Economic Change (Toronto: Macmillan Co., 1948), p. 172.

${ }^{48}$ H. W. Dickinson and Rhys Jenkins, James Watt and the Steam Engine (London: Oxford University Press, 1927), pp. 149-56; H. W. Dickinson, A Short History of the Steam Engine (London: Cass, 1963), pp. 79-82; Samuel Smiles, Lives of the Engineers: Boulton and Watt (London: John Murray, 1904), chap. 12.

${ }^{49}$ See William Fairbairn, An A ccount of the Construction of the Britannia and Conway Tubular Bridges (London, 1849); William Fairbairn, Useful Information for Engineers (London, 1860), 2:223-28, 244-64, 268-81, 282-92. 
Nathan Rosenberg

\section{Economic Development and Cultural Change}

view occasionally expressed during the 1950 s about heart attacks. Obviously, when stated this way, it is nonsense. Yet, if we qualify the proposition to state that "new constraints have sometimes proven beneficial," the proposition is obviously defensible ${ }^{50}$ ("Sweet-sometimes-are the uses of adversity"). The critical question is, of course, when, and under what circumstances? To answer this question in a nontautological or nontrivial way we would have to understand both the nature of the creative process and the working of social systems much better than we do at present. ${ }^{51}$

What is clear, however, is that there have existed a variety of devices at different times and places which have served as powerful agents in formulating technical problems and in focusing attention upon them in a compelling way. That there was an economic counterpart to this focusing process in the form of sharply rising prices, reductions in cost, and expectations concerning future

\footnotetext{
50 Similarly, a heart attack or other symptom of ill health may in fact be life-prolonging provided one (1) survives the initial attack and (2) interprets the medical signals correctly and makes appropriate modifications in future behavior. Thus, the ill health of David Ricardo's brother Moses was frequently referred to in Ricardo's correspondence. Moses gave up his medical practice at an early age and went to live in retirement at Brighton. Whereas poor David Ricardo, whose health had given no particular cause for alarm, died at the age of fifty-one, his "sickly" brother lived in to his ninetieth year, nursing his frail constitution to the very end (Piero Sraffa, ed., The Works and Correspondence of David Ricardo [London: Cambridge University Press, 1955], 10:56).

51 Having suggested avenues of exploration as obviously heretical as the foregoing, it is some consolation to be able to invoke the voice of Marshall (although admittedly an elderly Marshall) in an analogous line of reasoning. In accounting for Holland's earlier commercial supremacy, Marshall committed to print the following statement: "Holland seemed poor in physical resources: but her poverty was a part of her strength: for it led her to give her whole energies to developing those resources which she possessed" (Alfred Marshall, Industry and Trade [London: Macmillan Co., 1927], p. 692). Essentially the same view has been stated more recently by a distinguished economic historian: "Flanders owes its industry as much to its geographical limitations as to its geographical facilities" (M. M. Postan, in the Cambridge Economic History of Europe, ed. M. M. Postan and H. J. Habakkuk [London: Cambridge University Press, 1952], 2: 183). Similarly, Pirenne attributed Venice's early rise to commercial leadership to her lack of agricultural resources: "This ineluctable necessity was imposed on Venice from its very foundation on the sandy islets of a lagoon, on which nothing would grow. In order to procure a livelihood its first inhabitants had been forced to exchange salt and fish with their continental neighbours for the corn, wine and meat which they could not have obtained otherwise. But this primitive exchange inevitably developed, as commerce made the town richer and more populous, and at the same time increased its demands and sharpened its enterprise" (Henri Pirenne, Economic and Social History of Medieval Europe [London: Routledge, 1949], pp. 26-27). It is perhaps needless to add that Marshall, Postan, and Pirenne were well aware of the locational advantages which geography had conferred upon the places mentioned. No one seriously believes that poverty of resources,
} 
Nathan Rosenberg

profits hardly needs to be said. But the ordinary messages of the marketplace are general and not sufficiently specific. The market rewards reductions in cost, but this is true of all reductions in cost, wherever attained. It does not specify the directions in which cost reductions should be sought. The mechanisms examined here share the property of forcefully focusing attention in specific directions. They called attention decisively to the existence of problems the solutions to which were within the capacity of society at the time, and which had the effect of either increasing profits or preventing a decline that was anticipated with a high degree of probability.

These and other focusing devices deserve more careful examination in any serious exploration of the sources of technological change. It would be very interesting to examine, for example, the learning experiences and other creative opportunities associated with accidents and other disasters. Our ancestors, who had not yet taken to the air or experienced the fearful carnage of a motorized age, ${ }^{52}$ were nevertheless plagued by exploding boilers, collapsing bridges, and sinking ocean-going vessels. Although the cost was very high, much information was gleaned from these accidents, ${ }^{53}$ but, perhaps more important, they powerfully dramatized weaknesses in existing techniques and thus provided a strong impulse to research efforts. Disasters such as fires at sea were almost always followed by a rush of patent applications for devices which purportedly would prevent their recurrence. ${ }^{54}$ Nobel's invention of dynamite, a comparatively safe explosive, owed much to the unfortunate

by itself, is sufficient to generate economic growth. For an analogous argument in accounting for the growth of inventiveness in New England, see Daniel Boorstin, The Americans: The National Experience (New York: Random House, 1965), p. 22. For the suggestions that the origins of Mesopotamian civilization owed something to a regional shortage of resources, see Frank Hole, "Investigating the Origins of Mesopotamian Civilization," Science 5. (August 1966): 608.

52 The earliest advertisements for automobiles in weekly magazines frequently showed a team of runaway horses bearing down on oblivious bystanders (usually children at play) with indignant captions such as, "These horrible accidents must be stopped!" Next to this awful scene of impending disaster would be an illustration of a horseless carriage.

${ }^{53}$ The Firth of Forth bridge, e.g., incorporated improvements in design gleaned from the disastrous collapse of the Tay railway bridge in 1879 (see T. K. Derry and Trevor I. Williams, A Short History of Technology [London: Oxford University Press, 1960], pp. 449 and 457). The failure of bridges-especially railway bridges in the early days of railway construction - was an unfortunately common phenomenon. These dramatic accidents led to highly valuable public investigations (see, e.g., "Report of the Commissioners Appointed to Inquire into the Application of Iron to Railway Structures," Parliamentary Papers [1849], vol. 29). See also Fairbairn, The Life of Sir William Fairbairn, Bart., p. 187. On boiler explosions, see ibid., chap. 16.

54 "It is noteworthy that sensational accidents or unusual occurrences are followed immediately by a large influx of applications for patents connected in some way with them, 


\section{Economic Development and Cultural Change}

tendency of his shipments of nitroglycerin to explode in transit aboard railroad trains or, in some spectacular instances, in midocean. ${ }^{55}$ The nearly disastrous bursting of a hydraulic cylinder due to the enormous pressure to which it was subjected during the raising of the Britannia tubular bridge across the Menai Straits led directly to major advances in knowledge concerning the crystallography of metals. The new knowledge thus gained resulted in important improvements in design over a range of objects wherein cylinders were subjected to severe internal pressures, for example, cast-iron guns. ${ }^{56}$

All the cases dealt with have a common denominator in the expectation of profit, but in all cases also there are forces pointing emphatically in certain directions. This is the underlying unity. The inducement mechanism is the prospect of making extra-high profits, or the unbearable prospect of losing a marvelous and tangible opportunity to do so, just as in the cases of strikes and wars the mechanism is the unbearable prospect of being put out of business or having one's attempt at a more orderly planning process reduced to chaos. The kinds of agonizing uncertainties created by the imminent danger of a strike cannot be adequately reduced, as they often are in modern decision theory, to a probabilistic treatment. Probabilistic statements, by definition, do not apply to single events but only to classes of events. The employer, faced by a strike next week, cannot necessarily console himself with the thought that his situation is an unlikely one, and concentrate his attention on the mathematical expectation of the future. If the strike takes place, there may be no future-at least for his firm. It may well even be that the apparently irrational determination of so many nineteenth-century firms to introduce labor-saving innovations (irrational from the point of view of modern theory) really arose from their determination to engage in rational long-term planning-a procedure which was impossible as long as strike possibilities by indispensable skilled personnel hung like a sword of Damocles over their heads. ${ }^{57}$

as for example, devices to prevent fires at sea and for the protection of property following upon the L'A tlantique disaster and the epidemic of 'smash and grab' raids respectively" (H. W. Dickinson, “The Evolution of Invention," Proceedings, Institution of Mechanical Engineers [January 1934], p. 8).

55 Joseph Rossman, Industrial Creativity (New York: Universe Books, 1964), p. 128.

56 John Anderson, The Strength of Materials and Structures (London, 1872), pp. $280-$ 82; see also the Journal of the Society of Arts 17 (August 13, 1869): 746; and Edwin Clark, The Britannia and Conway Tubular Bridges (London, 1850), 2:690-94.

${ }^{57}$ Lebergott has argued that in the context of the American economy in the nineteenth century, entrepreneurial expectations concerning the trend of future wages justified a capital-intensive bias. "Given (1) a long run upward pressure on wages, and (2) an uncertain future course for the price of capital, the entrepreneur's wisest choice, time and again, proved to be: Adopt techniques that were not labor-intensive" (Stanley Lebergott, Manpower in Economic Growth [New York: McGraw-Hill Book Co., 1964], pp. 230-31). Lebergott also makes the interesting point that entrepreneurs who had recently immigrated to the United States regarded wages as "high" in some absolute

\section{2}


Nathan Rosenberg

It is possible, furthermore, that threats of deterioration or actual deterioration from some previous state are more powerful attention-focusing devices than are vague possibilities for improvement. There may be psychological reasons why a worsening state of affairs, or its prospect, galvanizes those affected into a more positive and decisive response than do potential movements to improved states. The same sort of asymmetry which Duesenberry postulated for consumer units confronted with the need to adjust to a downward revision in their incomes may hold for decision makers who control the allocation of resources for exploring the technological horizon. ${ }^{58}$ Such asymmetrical behavior may possibly be treated more appropriately within a "satisficing" model of entrepreneurial behavior and response, where alternative technologies are explored only when a firm's profit position falls below some minimum acceptable level. ${ }^{59}$ In any case, it is clear that threats to an established position have often served as powerful inducements to technical change. Finally, an important common denominator running through these

sense because they implicitly retained European wage-level standards. This tended to reinforce the capital-intensive bias (ibid., p. 231).

58 Somewhat analogously, Babbage asserted that depressed business conditions provided a strong stimulus to technical innovation (Babbage, p. 176). More recently it has been argued that machine tool producers introduce tools of new design during periods of depression in an attempt to offset the decline in the demand for their products (William Brown, "Innovation in the Machine Tool Industry," Quarterly Journal of Economics [1957], pp. 406-25). The argument is interesting and suggestive, if not entirely persuasive. Rostow at one point has combined the deterioration of business conditions with the downward inflexibility of wages as an explanation of labor-saving inventions. Writing of the British economy during the 1870 s, he suggests that "machinery was sought as a means of escaping the tyranny of money wages that could not be reduced. Everywhere 'the growing depression stimulated invention of labour-saving devices" " (W. W. Rostow, British Economy of the Nineteenth Century [New York: Oxford University Press, 1948], p. 75). Landes has recently argued that the loss of nearby markets for Swiss textile products at the end of the Napoleonic Wars "incited her textile industry to lower costs by mechanization and seek compensatory outlets in distant lands." Landes goes on to broaden his case by stating that "there is good reason to believe that adversity is at least as often a stimulus to achievement as a deterrent. It is no accident that techniques often achieve their highest development after the appearance of more efficient equipment or methods have rendered them obsolescent: recall the resistance of the sailing ship to the competition of steam, of puddling to that of the convertor and the open hearth, of coaching to the railway" (David Landes, "Factor Costs and Demand: Determinants of Economic Growth," Business History [January 1965], p. 31).

59 This signaling mechanism has its parallels, of course, in political processes. In discussing the problems of Brazil's underdeveloped Northeast province, Hirschman points out that "a bad drought usually jolts the government into a major new effort" (Albert Hirschman, Journeys toward Progress [New York: Twentieth Century Fund, 
Nathan Rosenberg

\section{Economic Development and Cultural Change}

historical examples is the persistence with which firms attack what, at any given time, they regard as the most restrictive constraint on their operations. This suggests that it may be possible to formulate a microeconomic approach to technical change in terms of a bottleneck analysis. If we would like to understand the kinds of problems to which technically competent personnel are likely to devote their attention, we must come to grips with their inevitable preoccupation with day-to-day problems posed by the existing technology. We might here invoke what March and Simon call "Gresham's Law of planning" which, succinctly stated, amounts to the proposition that "Daily routine drives out planning." $" 60$ If we pay more attention to the cues thrown out by this daily routine, we may gain a clearer understanding of the process of technical change.

1963], p. 18). As a signaling device, the threat to the established political order which is implicit in a failure to take a remedial-or at least a melioratory-action is similar to the threat to a business firm which fails to respond to a direct threat to its profit position. For a fascinating account of some of the other dimensions of the political problem in the context of recent Brazilian history, see ibid., chaps. 1 and 4. Dorfman has exhorted the economics profession to accept a view of the business firm which is very much in harmony with the approach suggested here: "We must recognize the firm for what operations research has disclosed it to be: of ten fumbling, sluggish, timid, uncertain and perplexed by unsolvable problems.... It reacts in familiar ways to the familiar and avoids the novel as long as it dares" (Robert Dorfman, "Operations Research," American Economic Review [September 1960], p. 622).

${ }^{60}$ James G. March and Herbert A. Simon, Organizations (New York: John Wiley \& Sons, 1958), p. 185. One might alternatively restate this as a short-run companion to Keynes's dictum: "In the long run we are all dead." It could then read: "In the short run we are all preoccupied." 